\title{
Lifecycle management of insecticides used for disease vector control: a global survey
}

Henk van den Berg

Wageningen Universiteit

\section{Haroldo Sergio da Silva Bezerra}

Organisation mondiale de la Sante

Emmanuel Chanda

Organisation mondiale de la Sante

Samira Al-Eryani

Organisation mondiale de la Sante

Bhupender Nath Nagpal

Organisation mondiale de la Sante

Elkhan Gasimov

Organisation mondiale de la Sante

Raman Velayudhan

Organisation mondiale de la Sante

Rajpal Singh Yadav ( $\sim$ yadavraj@who.int)

Organisation mondiale de la Sante https://orcid.org/0000-0001-8264-1204

\section{Research Article}

Keywords: Insecticide resistance monitoring, pesticide management, safety precautions, vector control operations

Posted Date: July 15th, 2020

DOI: https://doi.org/10.21203/rs.3.rs-41902/v1

License: (c) (i) This work is licensed under a Creative Commons Attribution 4.0 International License. Read Full License 


\section{Abstract}

Background: Vector control plays a critical role in the prevention, control and elimination of vector-borne diseases, and interventions of vector control continue to depend largely on the action of chemical insecticides. A global survey was conducted on the lifecycle management practices of vector control insecticides at country level to identify gaps to inform future strategies to improve efficacy of interventions and reduce the side effects of chemicals used on health and the environment.

Methods: A survey by questionnaire was disseminated among all WHO Member States on the lifecycle management practices of vector control insecticides at country level. Data were analysed using descriptive statistics.

Results: Responses were received from 94 countries, indicating a response rate of $48 \%$. Capacity for insecticide resistance monitoring has been established in part of the countries, often with external support; however, this capacity was lacking from other countries. Procurement of vector control insecticides was often taking place at decentralized levels, over which the central authorities lacked control, for example, to select the product or assure quality of the product. Moreover, some countries experienced problems with estimating the correct amounts for procurement, especially for emergency purposes. Countries across regions showed shortcomings in worker safety, pesticide storage practices, and pesticide waste disposal. Shortcomings were most pronounced in countries of the European \& Others Group, most of which have long been relatively free from mosquito-borne diseases but have recently faced challenges of re-emerging vector-borne diseases.

Conclusions: Critical shortcomings in the management of vector control insecticides are common in countries across regions, with risks of adverse pesticide effects on health and the environment. Advocacy and resource mobilization are needed at regional and country level to address these challenges.

\section{Background}

Human diseases transmitted by arthropod vectors account for approximately $17 \%$ of the estimated global burden of infectious diseases [1]. The most serious vector-borne diseases in terms of disease burden are malaria, dengue, lymphatic filariasis, onchocerciasis and leishmaniasis [2]. In many tropical and sub-tropical regions around the World, human populations are at risk from multiple vector-borne diseases [3]. The critical importance of vector control in managing these diseases has been emphasized [2, 4, 5]. For some diseases, such as dengue, zika and chikungunya, vector control and interruption of human-vector contact are the only available control options [6], for other diseases, like malaria, vector control has been playing a major role in control and elimination efforts [7].

The World Health Assembly recently adopted the Global Vector Control Response (GVCR) as strategy to strengthen capacity and coordination for vector control and public health entomology [1]. The GVCR is aligned with the key elements of the integrated vector management (IVM) approach, which seeks to make vector control more effective, efficient and sustainable, through evidence-based decision making, intersectoral collaboration, and an integrated approach to implementation $[8,9]$.

For the implementation of vector control, the GVCR calls for the use of efficacious interventions, with availability of high-quality vector control products, with capacity for optimal application, and minimizing the risks of pesticides to health and the environment. The mainstay methods for vector control still depend largely on the action of chemical pesticides (specifically, insecticides), applied on substrates, on water surfaces, as spatial spray, or impregnated in netting materials. Hence, appropriate management practices are required throughout the pesticide lifecycle, including on best practices of pesticide procurement, transport, storage, application and disposal [10]. Moreover, the routine 
monitoring and management of insecticide resistance is vital to preserve susceptibility to available vector control products in vector populations [11].

This paper describes the results of a global assessment on the lifecycle management practices of vector control insecticides at country level. The objective is to identify gaps to inform future strategies to strengthen pesticide management and, consequently, improve efficacy and reduce the adverse effects of pesticides on health and the environment.

\section{Methods}

A questionnaire was prepared on the use and application of pesticides for vector-borne disease control. Other public health pesticides, including those directly applied on humans, household pest control products, and professional public health pest control products were not the focus of the questionnaire. The study was part of a comprehensive assessment of the global situation of agricultural pesticides and public health pesticides; the results of the comprehensive assessment have been documented in a different form in a separate report [12].

The questionnaire was translated from English into French and Spanish and disseminated through e-mail as editable Word ${ }^{\circledR}$ document from WHO's headquarters via its regional and country offices to the national focal point in the Ministry of Health in each country. All 194 Member States of WHO were targeted. At country level, the national focal point was requested to have the questionnaire completed by the director of the main national vector-borne disease control programme (e.g. malaria, dengue), or (where applicable) by the national manager for vector control (i.e. person who has overall responsibility for entomological surveillance and vector control in the country). In countries with more than one national programmes for vector-borne disease control, the malaria programme or vector control manager was requested to coordinate completion of the questionnaire.

For analysis of results, countries were grouped according to the United Nations Regional Groups of Member States [13]. This classification differentiates the African, Asia-Pacific, Latin American \& Caribbean, Eastern European, and Western European \& Others Groups of countries. It is noted that the Western European \& Others Group includes Australia, Canada, New Zealand, and the United States of America in addition to Western European countries. Because only there were only four responses from the Eastern European Group, the data of the Eastern European Group were pooled together with those of the Western European \& Others Group into the 'European \& Others Group'.

Data were analysed using descriptive statistics. Only questions with binary or numeric responses were selected for analysis. Questions with narrative responses, questions that appeared to be ambiguous in retrospect, and several questions that had been used in a more broad-based pesticide study [14] were excluded from the analysis.

\section{Results}

By December 2018, questionnaire responses had been received from 94 countries, indicating a response rate of $48 \%$. The response rate was 54\%, 55\%, 76\% and 19\%, respectively, from the African, Asia-Pacific, Latin American \& Caribbean, and European \& Others Groups of countries.

Capacity for insecticide susceptibility testing (i.e. WHO or United States Centres for Disease Control and Prevention (CDC) phenotypic bioassays) was reportedly in place in most countries across regions, except in the European \& Others Group (Table 1). Representative sentinel sites, needed for monitoring of temporal changes in the prevalence of resistance, had been established in approximately half of the countries in the Africa, Asia-Pacific and Latin American \& Caribbean Groups (Table 1). Insectaries to support insecticide susceptibility testing and efficacy testing were reported 
to be in place in part of the countries across regions. Capacity for molecular testing and biochemical testing was reported from few countries but was most common in the African Group of countries (Table 1).

Table 1

Capacity for insecticide resistance monitoring

\begin{tabular}{|c|c|c|c|c|c|c|c|c|}
\hline \multirow[b]{2}{*}{ Topic } & \multicolumn{2}{|c|}{ African } & \multicolumn{2}{|c|}{$\begin{array}{l}\text { Asia- } \\
\text { Pacific }\end{array}$} & \multicolumn{2}{|c|}{$\begin{array}{l}\text { Latin American \& } \\
\text { Caribbean }\end{array}$} & \multicolumn{2}{|c|}{$\begin{array}{l}\text { European \& } \\
\text { Others }\end{array}$} \\
\hline & $\%$ & (n) & $\%$ & (n) & $\%$ & (n) & $\%$ & (n) \\
\hline Insecticide susceptibility testing & 68 & $(28)$ & 70 & (30) & 80 & $(25)$ & 30 & $(10)$ \\
\hline $\begin{array}{l}\text { Representative sentinel sites } \\
\text { established }\end{array}$ & 50 & $(28)$ & 57 & (30) & 36 & $(25)$ & 10 & $(10)$ \\
\hline Insectaries in place for bioassays & 57 & $(28)$ & 50 & (30) & 68 & $(25)$ & 40 & $(10)$ \\
\hline Molecular testing of resistance & 39 & $(28)$ & 17 & (30) & 28 & $(25)$ & 20 & $(10)$ \\
\hline Biochemical testing of resistance & 36 & $(28)$ & 20 & $(30)$ & 24 & $(25)$ & 20 & $(10)$ \\
\hline
\end{tabular}

Pesticide procurement is a demanding process to ensure the availability of correct amounts of quality products that are efficacious against targeted vectors. Most countries, apart from those in the European \& Others group, reported that the insecticide susceptibility status of vectors was used as a criterion for selection of pesticides to be procured (Table 2).

A small fraction of countries reported that problems were encountered with estimating the appropriate amounts of vector control insecticides to be procured for normal or routine situations (Table 2). However, a substantially larger fraction of countries experienced problems estimating the amounts needed for emergency situations (e.g. disease outbreaks), particularly in the African and Asia-Pacific Groups.

In most Asia-Pacific countries, a requirement for procurement of vector control insecticides was that quality control was conducted before and/or after shipment into the country (Table 2). This requirement was less common in the other regions. Pesticide procurement may benefit from regional collaboration. In this regard, half the countries in the Latin American \& Caribbean Group reported that procedures, requirements and guidelines for procurement were aligned with those of other countries in the (sub-) region, whilst such alignment was less common in other regions (Table 2). 
Table 2

Conditions and challenges of procurement of vector control insecticides

\begin{tabular}{|c|c|c|c|c|c|c|c|c|}
\hline \multirow[b]{2}{*}{ Topic } & \multicolumn{2}{|c|}{ African } & \multicolumn{2}{|c|}{$\begin{array}{l}\text { Asia- } \\
\text { Pacific }\end{array}$} & \multicolumn{2}{|c|}{$\begin{array}{l}\text { Latin American \& } \\
\text { Caribbean }\end{array}$} & \multicolumn{2}{|c|}{$\begin{array}{l}\text { European \& } \\
\text { Others }\end{array}$} \\
\hline & $\%$ & (n) & $\%$ & (n) & $\%$ & (n) & $\%$ & (n) \\
\hline $\begin{array}{l}\text { Insecticide susceptibility status as criterion for } \\
\text { selection }\end{array}$ & 89 & $(28)$ & 80 & (30) & 92 & $(25)$ & 38 & (8) \\
\hline $\begin{array}{l}\text { Problems estimating amounts needed for } \\
\text { routine/normal situations }\end{array}$ & 15 & $(27)$ & 27 & (30) & 8 & (24) & 13 & (8) \\
\hline $\begin{array}{l}\text { Problems estimating amounts needed for } \\
\text { emergency situations }\end{array}$ & 32 & $(28)$ & 40 & (30) & 17 & $(24)$ & 11 & (9) \\
\hline $\begin{array}{l}\text { Quality control (pre- and/or post-shipment) required } \\
\text { for procurement }\end{array}$ & 56 & $(27)$ & 73 & (30) & 36 & $(25)$ & 0 & (9) \\
\hline $\begin{array}{l}\text { Procurement requirements aligned with other } \\
\text { countries }\end{array}$ & 22 & (27) & 32 & (28) & 52 & $(25)$ & 20 & $(10)$ \\
\hline
\end{tabular}

Most countries, except in the European \& Others group, reported that the Ministry of Health procured pesticides for malaria control at central level (Table 3). For arboviral diseases and other vector-borne diseases, fewer countries in the African and Asia-Pacific groups reported central-level pesticide procurement (Table 3). In addition, in most countries there were other agencies or authorities (notably, local authorities, external programmes, private sector agencies) apart from the central-level procuring agency, that procured pesticides for vector control (Table 3 ). In $22 \%$ of responses, procurement was centralized only; in $20 \%$ of responses, procurement was decentralized only; and in $58 \%$ of responses, procurement was both centralized and decentralized.

WHO routinely evaluates vector control products, and publishes recommendations on approved products [15]. In most countries in the African and Asia-Pacific Groups, procurement by the central-level Ministry of Health was restricted to those products that have been recommended by WHO (Table 3). However, products that were procured by other agencies at decentralized level were less commonly restricted to WHO recommendations in most regions (Table 3).

WHO quality standards (i.e. pesticide specifications) were included in the procurement requirements by the centrallevel Ministry of Health in most countries, except in the European \& Others group (Table 3). However, for procurement at decentralized level by other agencies, quality standards were less commonly a requirement (Table 3 ). 
Table 3

Procedures for procurement of vector control insecticides

\begin{tabular}{|c|c|c|c|c|c|c|c|c|}
\hline \multirow[b]{2}{*}{ Topic } & \multicolumn{2}{|c|}{ African } & \multicolumn{2}{|c|}{$\begin{array}{l}\text { Asia- } \\
\text { Pacific }\end{array}$} & \multicolumn{2}{|c|}{$\begin{array}{l}\text { Latin American \& } \\
\text { Caribbean }\end{array}$} & \multicolumn{2}{|c|}{$\begin{array}{l}\text { European \& } \\
\text { Others }\end{array}$} \\
\hline & $\%$ & $(n)$ & $\%$ & $(n)$ & $\%$ & $(n)$ & $\%$ & $(n)$ \\
\hline Procurement for malaria control at central level & 63 & $(27)$ & 73 & $(30)$ & 84 & $(25)$ & 20 & $(10)$ \\
\hline Procurement for arboviruses at central level & 23 & $(26)$ & 57 & $(30)$ & 88 & $(25)$ & 11 & (9) \\
\hline $\begin{array}{l}\text { Procurement for other vector-borne diseases at } \\
\text { central level }\end{array}$ & 41 & $(27)$ & 55 & $(29)$ & 77 & $(22)$ & 10 & $(10)$ \\
\hline $\begin{array}{l}\text { Procurement of vector control pesticides at } \\
\text { decentralized level }\end{array}$ & 71 & $(28)$ & 72 & $(29)$ & 75 & (24) & 50 & (10) \\
\hline $\begin{array}{l}\text { Only WHO recommended products procured at } \\
\text { central level }\end{array}$ & 81 & (27) & 87 & (30) & 68 & (25) & 29 & (7) \\
\hline $\begin{array}{l}\text { Only WHO recommended products procured at } \\
\text { decentralized level }\end{array}$ & 76 & (21) & 50 & (20) & 35 & (17) & 40 & (5) \\
\hline $\begin{array}{l}\text { WHO quality standards used for centralized } \\
\text { procurement }\end{array}$ & 82 & (28) & 100 & (30) & 80 & (25) & 33 & (6) \\
\hline $\begin{array}{l}\text { WHO quality standards used for decentralized } \\
\text { procurement }\end{array}$ & 68 & (19) & 52 & (21) & 39 & (18) & 40 & (5) \\
\hline
\end{tabular}

Vector control spraying operations could adversely affect the health of spray workers, but health risks are reduced when adequate safety precautions are taken, for example, by using personal protective equipment. National guidelines or training curricula for safety precautions or risk reduction of spray workers for vector control operations were reportedly available in $70 \%$ of countries in the African, Asia-Pacific and Latin American \& Caribbean Groups (Table 4). However, national guidelines for health monitoring of spray workers in vector control operations (e.g. to detect signs and symptoms of pesticide poisoning) were present in only $11-44 \%$ of countries, depending on the region (Table 4), suggesting a major deficiency in health monitoring.

In countries where vector control operations were delegated or contracted to the private sector or to NGOs, these operations were monitored by the Ministry of Health in only part of the countries, suggesting that that there were many delegated or contracted vector control operations that were not monitored by the health authorities (Table 4).

Furthermore, it was reported that those responsible for decision-making and implementation of vector control activities received certified training in vector control in only a minority of countries, which indicates a deficiency in capacity building (Table 4).

Pest control operators (PCOs) are private sector companies engaged in the control of domestic and peri-domestic pest problems, including insect pests. In part of countries in each region, PCOs were required to be licensed or certified (Table 4); licensing may or may not have involved specific training for PCO staff. 
Table 4

Status of application of vector control insecticides

\begin{tabular}{|c|c|c|c|c|c|c|c|c|}
\hline \multirow[b]{2}{*}{ Topic } & \multicolumn{2}{|c|}{ African } & \multicolumn{2}{|c|}{$\begin{array}{l}\text { Asia- } \\
\text { Pacific }\end{array}$} & \multicolumn{2}{|c|}{$\begin{array}{l}\text { Latin American \& } \\
\text { Caribbean }\end{array}$} & \multicolumn{2}{|c|}{$\begin{array}{l}\text { European \& } \\
\text { Others }\end{array}$} \\
\hline & $\%$ & (n) & $\%$ & (n) & $\%$ & $(n)$ & $\%$ & $(n)$ \\
\hline $\begin{array}{l}\text { Guidelines for safety precautions of vector } \\
\text { control spray workers }\end{array}$ & 71 & (28) & 70 & (30) & 71 & (24) & 56 & $(9)$ \\
\hline $\begin{array}{l}\text { Guidelines for health monitoring of vector control } \\
\text { spray workers }\end{array}$ & 29 & (28) & 27 & (30) & 44 & (25) & 11 & $(9)$ \\
\hline $\begin{array}{l}\text { Delegated vector control operations adequately } \\
\text { monitored }\end{array}$ & 67 & (18) & 54 & (13) & 56 & (9) & 50 & $(6)$ \\
\hline $\begin{array}{l}\text { Vector control decision-makers trained in vector } \\
\text { control }\end{array}$ & 44 & (27) & 38 & (29) & 36 & (25) & 25 & (8) \\
\hline $\begin{array}{l}\text { Pest control operators required to be licensed or } \\
\text { certified }\end{array}$ & 65 & (26) & 63 & (30) & 56 & (25) & 88 & (8) \\
\hline
\end{tabular}

Vector control operations in which insecticides are used depend on a functional infrastructure for safe and secure transport and storage of insecticides and equipment. However, adequate, safe, and secure facilities for storing vector control insecticides at periphery level were available in only half of the countries and were least common in the Latin American \& Caribbean Group (Table 5). Moreover, stock keepers at periphery level with adequate training on stock management were lacking from a substantial proportion of countries across regions (Table 5). In only a minority of countries across regions it was required that the transport of vector control insecticides to stores or points-of-use was accompanied by a person trained on safe transport and emergency procedures (Table 5).

At the end of spray operations, empty insecticide containers (e.g. tins, flasks, sachets) should be safely disposed, to avoid their reuse or refilling, and rinsate (liquid used to rinse containers) should be reused [16]. However, most countries across regions lacked a national guidance document on the safe and environmentally sound disposal of pesticide containers (Table 5).

Pesticides become obsolete after having expired, when their contents or packaging have deteriorated, when they are no longer needed for vector control, or when they have become de-registered or banned. Accumulation of obsolete vector control insecticides was reportedly a problem in many countries in the African, Asia-Pacific and Latin American \& Caribbean Groups, but not in the European \& Others group (Table 5). 
Table 5

Status of storage, transport, and disposal of vector control insecticides

\begin{tabular}{|c|c|c|c|c|c|c|c|c|}
\hline \multirow[b]{2}{*}{ Topic } & \multicolumn{2}{|c|}{ African } & \multicolumn{2}{|c|}{$\begin{array}{l}\text { Asia- } \\
\text { Pacific }\end{array}$} & \multicolumn{2}{|c|}{$\begin{array}{l}\text { Latin American \& } \\
\text { Caribbean }\end{array}$} & \multicolumn{2}{|c|}{$\begin{array}{l}\text { European \& } \\
\text { Others }\end{array}$} \\
\hline & $\%$ & $(n)$ & $\%$ & $(n)$ & $\%$ & $(n)$ & $\%$ & $(n)$ \\
\hline $\begin{array}{l}\text { Secure pesticide storage facilities at periphery } \\
\text { level }\end{array}$ & 46 & $(28)$ & 55 & $(29)$ & 24 & $(25)$ & 67 & $(9)$ \\
\hline Trained pesticide storekeepers at periphery level & 60 & $(25)$ & 50 & $(30)$ & 65 & $(23)$ & 67 & $(9)$ \\
\hline $\begin{array}{l}\text { Pesticide transport personnel trained on safety, } \\
\text { emergency }\end{array}$ & 41 & $(27)$ & 37 & $(30)$ & 40 & $(25)$ & 33 & $(9)$ \\
\hline $\begin{array}{l}\text { Guidance on sound disposal of vector control } \\
\text { pesticide containers }\end{array}$ & 46 & $(28)$ & 48 & $(29)$ & 24 & (25) & 22 & (9) \\
\hline $\begin{array}{l}\text { Accumulation of obsolete vector control } \\
\text { insecticides not a problem }\end{array}$ & 56 & (27) & 60 & (30) & 48 & (25) & 100 & (10) \\
\hline
\end{tabular}

At institutional level, a national vector control unit, or body, with the responsibility for all vector control activities, was reportedly in place in most countries across regions, except for the European \& Others Group (Table 6).

The International Code of Conduct on Pesticide Management ('Code of Conduct') provides a framework for governments to manage pesticides throughout their lifecycle [10]. A small majority of countries reported that their Ministry of Health used, or referred to, the Code of Conduct in the management of public health pesticides. An exception were countries in the European \& Others Group where the Code of Conduct had reportedly not been used for public health pesticides (Table 6).

In some countries, the central-level Ministry of Health did not have available records on the use of vector control insecticides, suggesting that the authorities may not keep track of the amounts and types of insecticides used in the country (Table 6).

Table 6

Policy and institutional aspects of vector control

\begin{tabular}{|c|c|c|c|c|c|c|c|c|}
\hline \multirow[b]{2}{*}{ Topic } & \multicolumn{2}{|c|}{ African } & \multicolumn{2}{|c|}{$\begin{array}{l}\text { Asia- } \\
\text { Pacific }\end{array}$} & \multicolumn{2}{|c|}{$\begin{array}{l}\text { Latin American \& } \\
\text { Caribbean }\end{array}$} & \multicolumn{2}{|c|}{$\begin{array}{l}\text { European \& } \\
\text { Others }\end{array}$} \\
\hline & $\%$ & (n) & $\%$ & (n) & $\%$ & (n) & $\%$ & (n) \\
\hline National vector control unit in place & 82 & (28) & 70 & $(30)$ & 88 & $(25)$ & 30 & $(10)$ \\
\hline $\begin{array}{l}\text { Use of Code of Conduct for public health } \\
\text { pesticides }\end{array}$ & 78 & $(27)$ & 69 & (29) & 54 & $(24)$ & 11 & $(9)$ \\
\hline $\begin{array}{l}\text { Records available on use of vector control } \\
\text { insecticides }\end{array}$ & 71 & (28) & 82 & (28) & 80 & $(25)$ & 44 & $(9)$ \\
\hline
\end{tabular}

\section{Discussion}


The vectors of several human diseases are developing resistance to available insecticides [17-20]. Capacities needed for routine monitoring of insecticide resistance have been established in part of the countries in regions with high burden of vector-borne diseases, as indicated in this study. Recent capacity building efforts, in terms of a number of regional and national training courses on insecticide resistance monitoring, have likely contributed to this result [21, 22]. The standardized insecticide susceptibility tests, which measure phenotypic resistance, are the most common monitoring tools, but also have their limitations in terms of fluctuations in results and monitoring the intensity of resistance [5, 23-25]. Biochemical and molecular techniques are instrumental for identifying the mechanism of resistance and for detecting low frequencies of resistance genes in vector populations; however, these techniques depend on sophisticated equipment. Capacity for biochemical and molecular testing was most common in the African region, most likely in connection with recent investments into the region by malaria control and elimination programmes [26].

Despite these positive findings, many countries are apparently still lacking the basic capacities for insecticide resistance management. It is imperative that these countries will be able to generate insecticide susceptibility data for targeted insect vectors, to inform their decisions on vector control products and interventions. Nevertheless, a remaining challenge in many countries is how to interpret and use and the monitoring data on insecticide susceptibility for optimal decision making [21].

Another important finding is that, even though most countries have a system of centralized procurement of insecticides for vector-borne disease programmes in place, in many countries procurement is also taking place at decentralized levels by agencies other than the central-level Ministry of Health. Centralized procurement of pesticides, as for medical supplies, has advantages over decentralized procurement in terms of efficiency, control over product selection, negotiation on price and quality, quality control, and prevention of accumulation of expired stocks. A special concern is that decentralized procurements in responding countries gave less consideration to WHO-recommended products or quality standards as compared to centralized procurements. Moreover, decentralized procurements are less likely to be submitted to costly quality control, especially considering that quality control was generally weak across regions. Consequently, in many countries, procurements of vector control insecticides are taking place over which the central authorities apparently have little control.

A related issue is that a considerable number of countries expressed difficulties in estimating the amounts needed to be procured, especially for emergency situations. Under-estimation could have serious implications for outbreak control. Over-estimation could result in the accumulation of obsolete pesticides; the environmentally sound disposal of obsolete pesticides is known to be very costly [27]. For these countries, guidance or training tailored to their specific needs would be useful.

Aspects of worker safety, pesticide storage practices, and pesticide waste disposal are a common weakness in vector control programmes across regions, that can result in external costs of pesticides to health and the environment. This suggests that budgetary decisions by government agencies or donors have commonly emphasized the operations to achieve coverage of vector control, while financial and logistic support for health and environmental safety measures of those operations were often neglected. For example, independent observations in selected countries suggest that countries which opt for space spraying operations to control dengue fever in many cases do not have the available resources allocated to support health checks of spray teams, to provide insurance or compensation in case of pesticide poisoning, or even to provide the basic personal protective equipment [28]. This calls for critical review at country level. To guide policy reform, coordinated investigation into the prevalence of signs and symptoms of pesticide poisoning among vector control spray workers is needed, including on space spraying, a method which relies on airborne insecticide formulations. 
The European \& Others Group of countries have scored rather poorly in the survey, particularly in relation to the capacity for insecticide resistance monitoring, availability of guidelines, and vector control training. Most countries in this Regional Group have long been relatively free from mosquito-borne diseases, apart from introduced disease cases, and endemic leishmaniasis in the Mediterranean and Central Asia [29]. However, recent outbreaks of (re-) emerging vector-borne diseases like dengue, chikungunya and West Nile virus, together with the spread of invasive vectors, notably Aedes albopictus and Ae. aegypti, highlight the importance for countries in this group to establish adequate capacity to tackle these challenges [30-32].

A limitation of the study was that the focal points to which the questionnaires were addressed may not have had access to information regarding all questions. Moreover, the $48 \%$ response rate suggests that the data provided a moderate representation of the global situation.

Special efforts on advocacy and resource mobilization are necessary to assist countries in addressing their critical shortcomings in the management of vector control insecticides. At regional level, support could be provided for regional policy development, thematic technical support across countries, and in-depth analysis and planning in selected countries [33]. At country level, vector control programmes in which insecticides are used should make adequate budgetary allocation to insecticide resistance monitoring, pesticide procurement methods, worker safety, pesticide storage, and pesticide waste disposal.

\section{Conclusions}

Vector control interventions continue to depend largely on the action of chemical insecticides. Results from the global assessment indicate how vector control insecticides are managed throughout their lifecycle. Capacity for insecticide resistance monitoring has been established in part of the countries, often with external support; however, this capacity is still lacking from other countries. The procurement of vector control insecticides is often taking place at decentralized levels, over which the central authorities lack control, for example, on product selection or quality control. Moreover, some countries experience problems with estimating the correct amounts for procurement, especially for emergency purposes. Countries across regions showed critical shortcomings in worker safety, pesticide storage practices, and pesticide waste disposal. These shortcomings call for increased attention to pesticide lifecycle management in international support and budget allocation.

\section{Abbreviations}

CDC: United States Centres for Disease Control and Prevention; GVRC: Global vector control response; IVM: Integrated vector management; NGO: Non-governmental organization; PCO: Pest control operator; WHO: World Health Organization.

\section{Declarations}

\section{Ethics approval and consent to participate}

Not applicable

\section{Consent for publication}

Not applicable

\section{Availability of data and materials}


The anonymized dataset is available from the corresponding author upon reasonable request.

\section{Competing interests}

The authors declare that they have no competing interests.

\section{Funding}

The work was supported by the Bill \& Melinda Gates Foundation, Seattle, WA, as part of the Innovation-2-Impact project (grant ID OPP1133139).

\section{Authors' contributions}

RY, RV and HvdB conceived the study. HvdB and RY designed the questionnaire. HSB, EC, SAE, BNN, EG, and BNN supervised the data collection. HvdB analysed the data and drafted the manuscript. All authors contributed to manuscript revision and approved the final version.

\section{Acknowledgements}

WHO's Department for Control of Neglected Tropical Diseases thanks all those involved in Member States for assisting with the collection and validation of the questionnaire data. Staff of WHO at Regional Offices and Country Offices are gratefully acknowledged for their assistance in facilitating the questionnaire data collection process.

\section{References}

1. WHO. Global vector control response 2017-2030. Geneva: World Health Organization; 2017.

2. Wilson AL, Courtenay O, Kelly-Hope LA, Scott TW, Takken W, Torr SJ, Lindsay SW. The importance of vector control for the control and elimination of vector-borne diseases. PLoS Neglected Tropical Diseases. 2020;14(1):e0007831.

3. Golding N, Wilson AL, Moyes CL, Cano J, Pigott DM, Velayudhan R, Brooker SJ, Smith DL, Hay SI, Lindsay SW. Integrating vector control across diseases. BMC Med. 2015;13(1):249.

4. Townson H, Nathan MB, Zaim M, Guillet P, Manga L, Bos R, Kindhauser M. Exploiting the potential of vector control for disease prevention. Bull World Health Organ. 2005;83(12):942-7.

5. Hemingway J. The role of vector control in stopping the transmission of malaria: threats and opportunities. Philosophical Transactions of the Royal Society B: Biological Sciences. 2014;369(1645):20130431.

6. Roiz D, Wilson AL, Scott TW, Fonseca DM, Jourdain F, Müller P, Velayudhan R, Corbel V. Integrated Aedes management for the control of Aedes-borne diseases. PLoS Neglected Tropical Diseases. 2018;12(12):e0006845.

7. Bhatt S, Weiss DJ, Cameron E, Bisanzio D, Mappin B, Dalrymple U, Battle KE, Moyes CL, Henry A, Eckhoff PA. The effect of malaria control on Plasmodium falciparum in Africa between 2000 and 2015. Nature. 2015;526(7572):207-11.

8. WHO. Handbook for integrated vector management. WHO/HTM/NTD/VEM/2012.3. Available: http://whqlibdoc. who.int/publications/2012/9789241502801_eng.pdf. Geneva: World Health Organization; 2012.

9. WHO. A toolkit for integrated vector management in sub-Saharan Africa. WHO/HTM/NTD/VEM/2016.02. Geneva: World Health Organization; 2016.

10. FAO/WHO. International Code of Conduct on Pesticide Management. http://www.fao.org/fileadmin/templates/agphome/documents/Pests_Pesticides/Code/CODE_2014Sep_ENG.pdf. 
Rome and Geneva: Food and Agriculture Organization and World Health Organization; 2014.

11. WHO. Global plan for insecticide resistance management in malaria vectors.

http://whqlibdoc.who.int/publications/2012/9789241564472_eng.pdf. Geneva: World Health Organization; 2012.

12. WHO/FAO. Global situation of pesticide management in agriculture and public health. Report of a 2018 WHO-FAO survey. Geneva: World Health Organization and Food and Agriculture Organization of the United Nations; 2019.

13. United Nations Regional. Groups of Member States. https://www.un.org/depts/DGACM/RegionalGroups.shtml.

14. van den Berg H, Gu B, Grenier B, Kohlschmid E, Al-Eryani S, da Silva Bezerra HS, Nagpal B, Chanda E, Gasimov E, Velayudhan $\mathrm{R}$, et al. Pesticide lifecycle management in agriculture and public health: Where are the gaps? Sci Total Environ. 2020;742:140598.

15. WHO. List of WHO Prequalified Vector Control Product. http://www.who.int/pq-vector-control/prequalifiedlists/PQT_VC_17July2018.pdf?ua=1 Accessed: 21 January 2020; 2020.

16. FAO/WHO. Guidelines on management options for empty pesticide containers. Rome and Geneva: Food and Agriculture Organization of the United Nations and World Health Organization; 2008.

17. Moyes CL, Vontas J, Martins AJ, Ng LC, Koou SY, Dusfour I, Raghavendra K, Pinto J, Corbel V, David J-P. Contemporary status of insecticide resistance in the major Aedes vectors of arboviruses infecting humans. PLoS Negl Trop Dis. 2017;11(7):e0005625.

18. Ranson H, Lissenden N. Insecticide resistance in African Anopheles mosquitoes: a worsening situation that needs urgent action to maintain malaria control. Trends in Parasitology. 2016;32(3):187-96.

19. Dhiman RC, Yadav RS. Insecticide resistance in phlebotomine sandflies in Southeast Asia with emphasis on the Indian subcontinent. Infectious Diseases of Poverty. 2016;5(1):106.

20. Gomez MB, Diotaiuti LG, Gorla DE. Distribution of pyrethroid resistant populations of Triatoma infestans in the Southern Cone of South America. PLoS neglected tropical diseases 2016, 10(3).

21. Mnzava AP, Knox TB, Temu EA, Trett A, Fornadel C, Hemingway J, Renshaw M. Implementation of the global plan for insecticide resistance management in malaria vectors: progress, challenges and the way forward. Malaria Journal. 2015;14(1):173.

22. Corbel V, Durot C, Achee NL, Chandre F, Coulibaly MB, David J-P, Devine GJ, Dusfour I, Fonseca DM, Griego J: Second WIN International Conference on "Integrated approaches and innovative tools for combating insecticide resistance in vectors of arboviruses”, October 2018, Singapore. In.: BioMed Central; 2019.

23. Bagi J, Grisales N, Corkill R, Morgan JC, N'Falé S, Brogdon WG, Ranson H. When a discriminating dose assay is not enough: measuring the intensity of insecticide resistance in malaria vectors. Malar J. 2015;14(1):210.

24. Badolo A, Traore A, Jones CM, Sanou A, Flood L, Guelbeogo WM, Ranson H, Sagnon NF. Three years of insecticide resistance monitoring in Anopheles gambiae in Burkina Faso: resistance on the rise?. Malar J. 2012;11(1):232.

25. Sternberg ED, Thomas MB. Insights from agriculture for the management of insecticide resistance in disease vectors. Evol Appl. 2018;11(4):404-14.

26. Warren AE, Wyss K, Shakarishvili G, Atun R, de Savigny D. Global health initiative investments and health systems strengthening: a content analysis of global fund investments. Globalization Health. 2013;9(1):30.

27. Loha KM, Lamoree M, Weiss JM, de Boer J. Import, disposal, and health impacts of pesticides in the East Africa Rift (EAR) zone: A review on management and policy analysis. Crop Prot. 2018;112:322-31.

28. van den Berg $\mathrm{H}$, Velayudhan R, Yadav RS: Management of insecticides for use in disease vector control: Lessons learned from six countries in Asia and the Middle East (in preparation). 2020.

29. Dujardin J-C, Campino L, Cañavate C, Dedet J-P, Gradoni L, Soteriadou K, Mazeris A, Ozbel Y, Boelaert M. Spread of vector-borne diseases and neglect of Leishmaniasis, Europe. Emerg Infect Dis. 2008;14(7):1013. 
30. Schaffner F, Medlock JM, van Bortel W. Public health significance of invasive mosquitoes in Europe. Clin Microbiol Infect. 2013;19(8):685-92.

31. Rezza G: Dengue and other Aedes-borne viruses: a threat to Europe? Eurosurveillance 2016, 21(21).

32. Epidemiological update: West Nile virus transmission season in Europe, 2019

https://www.ecdc.europa.eu/en/news-events/epidemiological-update-west-nile-virus-transmission-season-europe2019.

33. van den Berg H, Yadav RS, Zaim M. Strengthening public health pesticide management in countries endemic with malaria or other major vector-borne diseases: an evaluation of three strategies. Malaria Journal. 2014;13(1):368.

\section{Additional File}

Additional file: Topics of the analysis with corresponding survey questions

\section{Supplementary Files}

This is a list of supplementary files associated with this preprint. Click to download.

- AdditionalFile.pdf 